\title{
Anal Cancer pN1 TNM Finding v6 and v7
}

National Cancer Institute

\section{Source}

National Cancer Institute. Anal Cancer pN1 TNM Finding v6 and v7. NCI Thesaurus. Code C67552.

Anal cancer with metastasis in perirectal lymph node(s). (from AJCC 6th and 7th Eds.) 